\title{
Factors Influencing the Appearance of Teaching Anxiety to Student Teachers
}

\author{
Ornela Bilali \\ Faculty of Educational Sciences, "Aleksander Xhuvani” University, \\ ornelabilali@gmail.com \\ Florinda Tarusha \\ Faculty of Educational Sciences, "Aleksander Xhuvani" University, \\ ftarusha@yahoo.com
}

\begin{abstract}
Student teachers who are involved in pedagogical practice during teaching experience anxiety. Anxiety of teaching is influenced by a number of factors that are associated with specific characteristics of learning situations. The aim of the study was to determine the factors that influence the birth of anxiety to student teachers during teaching. Participants in this study were students of the Faculty of Education, "Alexander Xhuvani" University, enrolled in programs of study: "Elementary Teacher" and "Preschool Teacher". Resulted that the teaching anxiety to student teachers influenced by a number of factors that are associated with specific characteristics of learning situations as: teaching planning, ability to analyze problems of learning, class management, assessment of students, public speaking. Teaching observation from mentor teacher, lecturer, students of course, was a factor that intrigued most students.
\end{abstract}

Keywords: teaching anxiety, student teachers, pedagogical practice

\section{INTRODUCTION}

Teaching practice has always been defined as the possibility for student teachers to perform teaching in a school situation (Ngcobo, 1995). Prospecting (McBride, 1984: 41; Wendt \& Bain, 1989: 178; Behets, 1990: 73) has shown that student teachers are concerned by teaching in pedagogical practices. They experience anxiety during teaching.

Much research has been conducted to study the nature of the anxiety of teaching to student teachers and the factors associated with the manifestation of anxiety during teaching experiences. In Great Britain it was found that anxiety is associated with factors such as professional concerns, evaluation of students, classroom control, learning the demands of practice (Hart, 1987). In Canada reported that anxiety to student teachers is related to pedagogy, assessment, classroom management and staff relationships (Morton, Vesco, Williams \& Awender, 1997). In Albania it is not encountered any research on teaching anxiety and factors affecting its birth, to student teachers during teaching experiences.

During practice, most student teachers are concerned about the evaluation (Capel, 1997, Morton, at. al, 1997). Are often uncertain about what standards will be met or will be met. Teaching concerns about standards generally result: concerns about tasks, student learning, concerns implementation of effective teaching (Griffen-Jeansonne and Calista, 1984). Fuller (1969) found that the assessment of students and supervisors bring concerns to student teachers.

The empirical findings support the idea that the high level of anxiety among student teachers can be associated with negative consequences such as classroom control problems, and concerns in the classroom. Preece (1979: 18) found a correlation between student anxiety for teachers and classroom control problems. This conclusion supports by Hart (1987: 16) which reported a positive correlation between student anxiety and concerns teachers in the classroom.

The intensity of anxiety respondents emphasizes Gardener and Leak (1994) was positively associated with several variables such as negative experience in the classroom, teaching with younger students, teaching of unknown materials. 
Likewise Ameen, Elsie C; Daryl M. Guffey \& Cynthia Jackson (2002), found that $80 \%$ of respondents with teaching anxiety, stated as possible causes non recognition of materials and students, pre-preparation class, student evaluation. Thompson (1963) found that students of teachers have expressed concerns about: student discipline, mastery of content, inability to answer questions and to design lesson plans.

\section{Purpose and Objectives}

The purpose of this study was to highlight the factors that affect the birth of anxiety during teaching to student teachers. Students with anxiety not seek help from mentors or tutors for the concerns that they have (Rickinson, 1998). By discovering and determine the factors that affect the birth of anxiety to these students, we can contribute later with other studies to find how to intervene to reduce the level of anxiety among students during teaching in pedagogical practices.

\section{METHODOLOGY}

\section{Participants}

Participants in this study were students of the Faculty of Education, University "Alexander Xhuvani", Elbasan. Students were enrolled in the study programs: "Elementary Teacher" and "Preschool Teacher". In this study participated 100 students by age 19- 25 years old (mean age 22vjeç). Of these 52 students (52\%) were enrolled in the study program "Elementary Teacher" and 48 others (48\%) in the study program "Preschool Teacher." Students participating voluntarily participated in this study, thereby defining the pattern of random selection of the sample.

\section{Instruments}

The instrument used was a two-page self-report questionnaire with demographic information including age and study program as well Teaching Anxiety Scale (Parsons, 1973).

The Teaching Anxiety Scale (TCHAS) aims to assess participants' self-reporting of their feelings and tensions while they are teaching. The participants responded to each statement using a 5-point Likert scale for the frequency of experiencing certain anxiety behaviors ranging from 1 (never) to 5 (always). TCHAS contains a variety of self-reporting statements, reaction of teachers about teaching. This reaction is of two kinds: first, as an emotional response to situations of different variety of teaching, the second as an approach to teaching as a profession. First rate service helps teachers identify weak points and strengths of their teaching.

\section{Data Analysis}

The data were entered in the statistical analysis program SPSS version 17 and analyzed using Descriptive statistics: averages, standard deviation, frequency

\section{DISCUSSION AND CONCLUSION}

\section{Supervision of teaching}

Informing the student teachers by the director to the observation of teaching, teaching observation by supervisors, evaluation, supervision and teaching therefore brings concerns to student teachers favoring them, teaching the birth of anxiety (table 1). This conclusion is supported by the literature as and Fuller (1969) found that the assessment of students and supervisors brings concern to student teachers.

\section{Table 1 Supervision of teaching}

I would feel anxious if the principal informed me he was coming to my class to observe.

I feel nervous when I am being observed by my college supervisors.

I would feel calm and collected if a student's parent observed in my classroom. 


\section{Teaching competences}

Factors like: Confidence in the competences of teaching, teaching planning, the ability to keep control of the class, the ability to mastering the content, links with other teachers, the ability to present, the effectiveness of schools, public speaking are directly related factors with teaching competences (table 2) required of teachers in the teaching role. This conclusion finds support and in studies conducted by researchers such as Thompson (1963) which states that students teachers have showing concern with: student discipline, mastery of content, inability to answer questions and to design lesson plans. Ameen at al. (2002) noted that experience in teaching anxiety is related to causes such as unfamiliarity materials and students, pre-preparation class, assessment of students. Preece (1979: 18); Hart (1987: 16) found a correlation between teaching anxiety and control problems.

\section{Table 2Teaching competences}

I feel that students will follow my instructions.

I feel uncomfortable when I speak before a group.

\begin{tabular}{l|l} 
I (would find) find it easy to speak up in the staff room. &, 84
\end{tabular}

I feel better prepared for teaching than other preservice teachers in my teacher preparation program.

If I have trouble answering a student's question I (will find) find it difficult to concentrate on questions that follow.

I feel calm and collected when I think about holding parent-teacher conferences.

I feel I (will be) am as competent in the classroom as other preservice teachers in my teacher preparation program.

I (would find) find it easy to admit to the class that I don't know the answer to a question a student ask.

Lack of rapport with my students (will be) is one of my biggest worries.

I feel confidet about my ability to improvise in the classroom.

I feel other teachers (will think) think I'm very competent.

I (would feel) feel panicky when a student asks me a question I (couldn't) can't answer.

I'm concerned about how to use testing of students as a useful indication of how effectively l'm teaching them.

I feel inferior to other preservice teacher in my teacher preparing program.

I'm worried that differences in background between my students and me (will prevent) prevent me from 
I am certain that my own personal "hangs up" (will not) do not hinder my teaching effectiveness

\begin{tabular}{|l|}
\hline, 73 \\
8 \\
, 72 \\
7 \\
, 72 \\
2 \\
, 72 \\
0 \\
, 71 \\
4 \\
, 71 \\
1 \\
, 66 \\
7
\end{tabular}

I am uncertain whether I (will be able to) can tell the difference between really seriously disturbed students and those who are merely "goofing off" in class

I am worry about being able to keep students interested in what I (will teach) teach them

I feel I will have good recallof the things I know, when I am in front of the class.

I feel secure with regard to my ability to keep a class under control.

Deciding how to present information in the classroom (would makes) makes me feel uncertain.

I (would feel) feel calm (If I were) when I am preparing lessons.

71

66

\section{Teaching as a profession}

Students are concerned the fact that not very happy during the teaching. The dilemma of choosing correct or not teaching as a profession as satisfactory intriguing to most of students. The student teacher decides to question his safety if he really wants to become a teacher or not (table 3 ).

Table 3 Teaching as a profession

\begin{tabular}{l|c|}
\hline I am less happy teaching, and that I thought I will be. &, 810 \\
I feel sure I will find teaching a satisfying profession. &, 752 \\
I feel anxious because I don't know yet whether I really want to be a teacher. &, 692 \\
I'm worried whether i can be a good teacher &, 676 \\
\hline
\end{tabular}

In this study it was found that anxiety of teaching is influenced by a number of factors that are associated with specific characteristics of learning situations as teaching planning, the ability to analyze problems and learning, classroom management, student assessment i.e. teaching competences. Supervision of teaching from mentor teacher, lecturer, students of the course, was a factor that intrigued most of students.

\section{References}

[1] Ameen, Elsie C., Daryl M. Guffey, and Cynthia Jackson. (2002) "Evidence of Teaching Anxiety Among Accounting Educators." Journal of Education for Business 78.1: 16-22.

[2] Behets, D. (1990). Concerns of preservice physical education teachers. Journal of Teaching in Physical Education, 10:66-75.

[3] Capel, S. A. (1997). Changes in students'anxieties and concerns after their first and second teaching practices. Educational Research, 39, 211-228.

[4] Fuller, P.F. (1969). Concerns of teachers: A developmental conceptualization. American Educational Research Journal, 6, 207-226. 
[5] Gardener, L. E. \& Leak, G. K. (1994). Characteristics and correlates of teaching anxiety among college psychology teachers. Teaching of Psychology, 21(1), 28 -32.

[6] Griffin-Jeansonne, Carol and Edward R. Caliste. (1984). "Pupil Perceptions of Teachers as a Function of Teacher Concerns." Education 104.3, 250-257.

[7] Hart, N.I. (1987). Student teacher anxieties: four measured factors and their relationships to pupil disruption in class. Educational Research, 29:12-18.

[8] McBride, R.E. (1984). Perceived teaching and program concerns among preservice teachers, university supervisors, and cooperating teachers. Journal of Teaching in Physical Education, 3:36-43.

[9] Morton LL, Vesco R, Williams NH \& Awender MA (1997). Student teacher anxieties related to class management, pedagogy, evaluation, and staff relations. British Journal of Educational Psychology, 67:69-89.

[10] Ngcobo, B.W. (1995).A didactic paradigm for school-based practice teaching for colleges of education in KwaZulu-Natal. DEd thesis.

[11] Parsons, J.S. (1973). Assessment of anxiety about teaching using the Teaching Anxiety Scale: Manual and research report. The Research and Development Center for Teacher Education University of Texas. ERIC ED 079330

[12] Preece, P.F.W. (1979). Student teacher anxiety and class-control problems on teaching practice: a cross-lagged panel analysis. British Educational Research Journal, 5:13-19.

[13] Wendt, J.C. \& Bain, L.L. (1989). Concerns of preservice and inservice physical educators. Journal of Teaching in Physical Education, 8:177-180. 